\title{
SS18/SSX4 Fusion Gene
}

National Cancer Institute

\section{Source}

National Cancer Institute. S518/SSX4 Fusion Gene. NCI Thesaurus. Code C99397.

A fusion gene $(\sim 2.9 \mathrm{~kb})$ that results from a chromosomal translocation $\mathrm{t}(\mathrm{X} ; 18)$

(p11.2;q11.2) which fuses exon 10 of the SS18 gene to exon 6 of the SSX4 gene. This fusion is associated with synovial sarcoma. 